\title{
CALDERON COKEMAKING \\ PROCESS/DEMONSTRATION PROJECT
}

Quarterly Technical Report

Reporting Period: 05/26/1997 through 08/25/1997

Author: ALBERT CALDERON

Report Issue Date: 09/24/1997

DE-FC22-95PC92638

\section{CALDERON ENERGY COMPANY}

500 Lehman Avenune

P.O. Box 126

Bowling Green, OH 43402 


\section{DISCLAIMER}

This report was prepared as an account of work sponsored by an agency of the United States Government. Neither the United States Government nor any agency thereof, nor any of their employees, makes any warranty, express or implied, or assumes any legal liability or responsibility for the accuracy, completeness, or usefulness of any information, apparatus, product, or process disclosed, or represents that its use would not infringe privately owned rights. Reference herein to any specific commercial product, process, or service by trade name, trademark, manufacturer, or otherwise does not necessarily constitute or imply its endorsement, recommendation, or favoring by the United States Government or any agency thereof. The views and opinions of authors expressed herein do not necessarily state or reflect those of the United States Government or any agency thereof. 


\section{QUARTERLY TECHNICAL PROGRESS REPORT \\ CALDERON COKEMAKING PROCESS/DEMONSTRATION PROJECT \\ CALDERON ENERGY COMPANY}

COOPERATIVE AGREEMENT NO. DE-FC22-95PC92638

Reporting Period: 5-26-97 to 8-25-97

Date of Report: 9-24-97; $\quad$ Award Date: 5-25-95; Anticipated Completion Date: 11-25-98

Total Project: $\$ 7,354,195.00 \quad$ Total DOE Share: $\$ 3,039,389.00$

Contracting Officer's Representative (COR): Mr. Michael J. Baird

Project Director: Albert Calderon

$\underline{\text { Abstract }}$

This project deals with the demonstration of a coking process using Calderon's proprietary technology for:

(i) making coke of such quality as to be suitable for use in high driving blast furnaces; and

(ii) providing proof that such process is continuous and environmentally closed to prevent emissions.

The activities of the past quarter were entirely focused on the rehabilitation of Calderon's Process Development Unit (PDU-I) in Alliance, Ohio to conduct a series of tests under steady state using coal from Bethlehem Steel and U.S. Steel in order to demonstrate the above. 


\section{TABLE OF CONTENTS}

$\begin{array}{ll}\text { Introduction } & \text { Page } 1\end{array}$

Accomplishments and Discussion

Page 1

Other Issues

Page 4

Conclusion

Page 5 


\section{$\underline{\text { Introduction }}$}

The road to commercialize the Calderon cokemaking process consists of the following phases:

Phase I-- Proof of capability to produce acceptable product coke, and proof of the process being environmentally closed.

Phase II-- Scale-up of coking reactor to full commercial size (PDU-II) in support of first commercial facility

Phase III-- Construction and operation of first commercial facility

Phase IV-- Worldwide commercialization of the technology

In order to get the support of the steel industry in the demonstration of the Calderon process, U.S. Steel and Bethlehem Steel were approached to participate in tests using their coals to make high quality blast furnace coke in Calderon's Process Development Unit (PDU-I) located in Alliance, Ohio, which was mothballed in 1992. The activities of the last quarter focused on the reactivation of PDUI.

\section{Accomplishments and Discussion}

To keep expenses down in the reactivation of PDU-I, it was decided that only the equipment that is absolutely necessary to demonstrate that high quality blast furnace coke can be made, would be utilized. The work carried out covered the following categories:

\section{Site Preparation}

Since no coal was pyrolyzed at the site for almost five (5) years, the site was cleared of debris, grass mowed, office trailer roof repaired, telephone lines re-established and air conditioners checked.

\section{Elevator}


The elevator was checked for being safe to use; during such check, the brakes and drive were replaced. The gear racks were greased and the cab was painted.

\section{Coal Handling}

The skip hoist was checked. One of the rollers of the skip bucket was replaced. The runway, rollers and cable were lubricated. The scale under the bucket in the down position was checked and calibrated. A load cell needed replacement.

\section{4. $\quad$ Coal Feed}

The lockhopper for the coal is serviced by a ball valve at the top, a feeder at the bottom and a second ball valve below the feeder. The valves were greased and cycled and the shaft of the feeder which was frozen had to be freed. The rod that is connected to the ram that pushes the coke was pitted from oxidation; it was gone over with emery cloth and polished in order to prevent damage to the seals. All bolting which corroded was wire-brushed, blown clean and heavily greased to prevent rust from being carried inadvertently into the seals.

\section{Hydraulic System}

The hydraulic pumps which are located at ground level were checked. The oil was found to be serviceable despite its being uncirculated for several years. Since the system operates at $3000 \mathrm{psi}$, for safety new hydraulic hoses and filters were installed.

\section{6. $\quad$ Air Compressors}

The facility is serviced by two primary compressors to compress shop air and one secondary compressor to compress instrument air. These compressors were checked and despite their idleness of several years, they were found to be serviceable except for change of filters; they were cleaned and painted. 


\section{Structural Changes}

The structural changes were a penetration into the elbow at the end of the coking reactor for the mounting of an optical pyrometer to read the temperature of the coke at the center of the coke; a spool above the vessel which contains the expansion joint; a blind mounted on a rail car located below the quencher (previously the gasifier); a boot to collect the coke from the quencher; and four

additional penetrations for thermocouples provided in the shell of the reactor to read a profile of temperatures along the length of the reactor.

\section{8. $\quad$ Burner Checkout}

The burner which provides thermal energy to the coking reactor was disconnected and checked. The fire-eye was cleaned, and the burner was re-gasketted and re-assembled.

\section{Electrical Work}

Little electrical work was required except for the wiring necessitated by the number of thermocouples which were added to the system.

\section{Controls Re-programming}

Since the process of coking for the forthcoming tests obviated the necessity for the boiler, the hot gas cleanup, the gasifier, and slag quenching, a new program had to be instituted; this was a lengthy procedure approximating ten days of work.

\section{Piping}

The piping work covered several parts; namely piping for water injection into the flue gas for cooling; piping for combustion air for burning the process gas and piping for water injection to cool the combusted process gas; piping for nitrogen purging at various points in the process was installed as an entirely new system and connected to a trailer serviced by a gas company. 


\section{Tools}

The front-end loader needed major service work. Miscellaneous hand tools had to be purchased.

\section{Safety and Office Equipment}

All the safety equipment which had been in place was checked and recalibrated. Some gas analyzing equipment for $\mathrm{CO}$ and hydrocarbons was added. Safety coats, helmets, and face shields were acquired. Miscellaneous office equipment and supplies were purchased.

\section{Coal Storage}

Areas were cleared to receive the four different blends of metallurgical coals. One blend was from Bethlehem Steel and three from U.S. Steel. The different coal blends were put in four separate areas to prevent the mixing of the blends. Each area was identified and covered with tarps in order to keep out the rain.

\section{Manpower Recruiting}

The recruiting of manpower for such a limited period for reactivation and testing (about four months) is somewhat taxing by virtue of the need to train people to operate and maintain the facility. It was decided to work a schedule of ten hours/day during reactivation and two (2) 12 hour shifts during operation. Training of operators was begun as soon as the programming of the control system was completed.

\section{Other Issues}

(i) The draft of the permit for the installation of PDU-II has been issued by the Ohio EPA. It is being published in the Mahoning County legal news for comments.

(ii) The preparation of the feasibility assessment to make use of the syngas to be produced from the Calderon cokemaking process, as a gas to reduce iron ore for the co-production of coke and 
DRI has been completed. The findings show that the approach is sound both technically and economically.

\section{Conclusion}

The next quarter's objectives is to operate PDU-I to produce coke of blast furnace quality for U.S. Steel and Bethlehem Steel, and also to demonstrate that the Calderon process is environmentally closed. Start-up is scheduled for the 8th of September 1997.

Submitted by:

Albert Calderon
Project Director 